it is because $I$ live in a cement manufacturing center which early enjoyed the benefits of hard surfaced roads, I wonder whether the lack of highly mechanized systems of construction and satisfactory surfacing materials might not have been a contributing cause for the abandonment of these early schemes for road improvement.

In 1904, fifty years after the era of Plank Roads in Iowa, only $7.14 \%$ of the nation's highways were improved. lowa and the nation had to await the demand of a motorized civilization before the hopes of James Weed, John Culbertson, William Abbey, Thomas Way, and the rest of those pioneers in highway construction, had their fruition in a maze of improved highways, many of which follow the very trails those pioneers blazed.

Those old roads upon which our pioneer forebears journeyed are gone. The ruts and stones over which they bumped with stoic patience are today smooth ribbons of concrete and only here and there in some bit of virgin timber do we find the deep worn ruts along which ox teams and stages brought civilization to the west. ${ }^{27}$ In very truth, Transportation is, Crvilization.

\title{
THE PROPOSED KEOKUK-FORT DES MOINES PLANK ROAD
}

The main trunk-if I may so term it-would run through the flourishing towns along the ridge, having lateral roads or branches, ranging in length from three to ten miles, to the various beautiful little towns on the banks of the Des Moines and Skunk Rivers.

Every farmer within ten miles of the road should be willing to furnish a few thousand feet of lumber, or to take his team. and grade a section of the road and take the amount in stock. . . The investment would be a very profitable one, such roads having generally paid dividends ranging from 25 to 50 per cent.—quoted from the "Whig and Register" (Keokuk papers) by the Iowa Star (Fort Des Moines), March 1, 1850.

\footnotetext{
${ }^{27}$ A few miles southwest of Mason City, in Owen's Grove, early settled by Cerro Gordo County pioneers, one can still see the ruts of the route taken by stages and private teams from Waterloo and Rockford to Mason City, the route which brought settlers to the latter city eighty-five years ago.
} 
Copyright of Annals of Iowa is the property of State of Iowa, by \& through the State Historical Society of Iowa and its content may not be copied or emailed to multiple sites or posted to a listserv without the copyright holder's express written permission. However, users may print, download, or email articles for individual use. 